\title{
ANALISIS PERAN BELANJA MODAL DAN INVESTASI SWASTA TERHADAP PERTUMBUHAN EKONOMI SERTA DAMPAKNYA PADA KESEJAHTERAAN MASYARAKAT
}

\author{
Akhlis Priya Pambudy \\ Muhamad Imam Syairozi \\ Program Studi Manajemen Universitas Islam Lamongan \\ akhlis@unisla.ac.id \\ imamsyairozi@unisla.ac.id
}

\begin{abstract}
The purpose of economic development is to improve public welfare. Many factors influence economic growth, including sustainable development. This study is aimed to analyze the impact of capital expenditure and private investment on economic growth of the regency/municipal during the period of 2010-2015 as well as the impact of economic growth on public welfare proxied by the human development index figures. Using WarpPLS, used purposive sampling methode, testing is done for the 415 autonomous regional and 93 autonomous municipals in Indonesia using time series data 2010-015. The results of this study shows that capital expenditure positively effect economic growth as well as private investment has positive effect on economic growth. Furthermore, the economic growth has been proven to improve public walfare.
\end{abstract}

Keywords: capital expenditure, private investment, economic growth, public welfare

\section{PENDAHULUAN}

Salah satu strategi pemerintah untuk mendorong pertumbuhan ekonomi adalah melalui percepatan pembangunan. Pembangunan infrastruktur memegang peranan yang penting dalam pertumbuhan eknomomi, seperti yang disampaikan oleh Suhariyanto, Deputi Bidang Neraca dan Analisis Statistik Badan Pusat Statistik, kepada Antara dalam situs www. antaranews.com bahwa pertumbuhan ekonomi sebesar $5,7 \%$ yang dicanangkan pemerintah pada tahun 2015 sangat tergantung dari pencapaian pelaksanaan pembangunaninfrastruktur. Namun, untuk mendorong percepatan pembangunan infrastruktur tidak hanya menjadi tanggung jawab pemerintah saja, partisipasi swasta juga sangat dibutuhkan. Menurut pendapat
Rodrigo Chaves, Kepala Perwakilan Bank Dunia untuk Indonesia pada situs resmi Kementrian Keuangan Republik Indonesia menyatakan bahwa dengan meningkatnya investasi infrastruktur berkelanjutan dalam penyediaan air bersih, sanitasi, transportasi umum yang efisien, dan perumahan terjangkau, kota-kota di Indonesia dapat mempercepatpertumbuhan dan mengangkat jutaan rakyat keluar dari kemiskinan. Pada laporan Rencana Strategi Badan Koordinasi Penanaman Modal Tahun 2015-2019 dijelaskan bahwa pertumbuhan ekonomi pada periode 2010-2014 terutama didorong oleh pertumbuhan investasi (Pembentukan Modal Tetap Bruto/PMTB) yaitu rata-rata $6,8 \%$ dan ekspor barang dan jasa (periode 2010-2011). Peran investasi terhadap pertumbuhan ekonomi semakin besar yang 
tercermin dari terus meningkatnya kontribusi PMTB dalam Produk Domestik Bruto (PDB) yaitu dari $21,0 \%$ pada tahun $2004,31,0 \%$ pada tahun 2010 , menjadi $32,6 \%$ pada tahun 2014. Sebagai contoh, pembangunan jalan tol di Kabupaten Pasuruan menjadi insentif yang menarik bagi para investor karena sektor swasta dapat menghemat biaya transportasi.

Dampak nyata bagi Kabupaten Pasuruan sendiri adanya peningkatan nilai investasi sebesar Rp5 triliun, dari Rp10 triliun pada tahun 2014 naik menjadi Rp15 triliun pada tahun 2015. Contoh lain, investasi sektor swasta meningkat di Kota Cirebon dengan berdirinya 30 hotel baru dalam kurun waktu dua tahun belakangan ini. Pembangunan hotel ini disebabkan adanya pembukaan jalur tol Cikopo-Palimanan (Cipali) Kota Cirebon - Jawa Barat. Dampak positif pembangunan infrastruktur di Provinsi Banten dapat dilihat pada sektor industri pengolahan yang namun pada triwulan III 2015 mengalami kenaikan permintaan, yang tercermin dari meningkatnya indeks produksi baja. Kenaikan permintaan baja merupakan dampak dari kerjasama yang dilakukan pemerintah dalam rangka pembangunan proyek infrastruktur, yang

menghimbauparapelaksanaproyekuntuk menggunakan baja nasional. Bedasarkan data Badan Kordinasi Penanaman Modal (BKPM), nilai investasi hingga triwulan III 2015 di bidang infrastruktur mencapai Rp90,5 triliun. Angka tersebut tumbuh 12,4 persen dibandingkan periode yang sama tahun 2014 lalu.

Kondisi infrastruktur di Papua yang belum memadai dan memenuhi kebutuhan baik untuk bisnis maupun masyarakat, berdampak pada perlambatan ekonomi di masyarakat. Oleh karena itu, pemerintah menaruh perhatian khusus pada pertumbuhan ekonomi Papua dengan

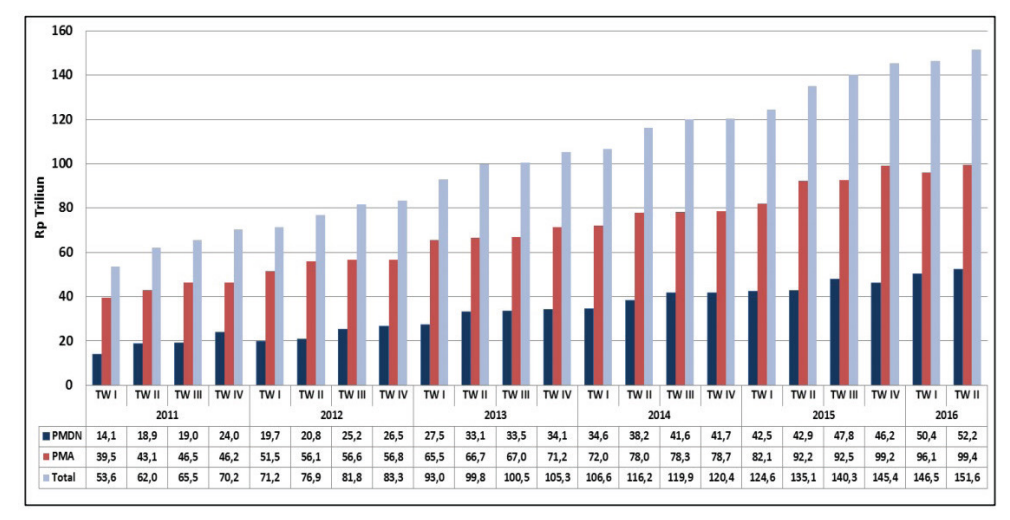

Sumber: BKPM

\section{Gambar 1}

Perkembangan Realisasi Investasi 2011-2016

meningkat secara signifikan sebesar 3,44 persen pada triwulan III 2015. Angka ini lebih besar dari triwulan II 2015 yang hanya mencapai 2,58 persen.

Peningkatan ini dapat dijelaskan sebagai dampak dari adanya kenaikan permintaan pada industri logam dasar atau baja yang sebelumnya sempat mengalami perlambatan akibat serbuan baja impor, mengalokasikan dana sekitar Rp12,5 triliun untuk menyelesaikan jalan trans Papua. Dana tersebut untuk membangun jembatan danjalan sepanjang $900 \mathrm{~km}$. Padatahun 2015 pemerintah memberikan dana Rp6 triliun ke Papua yang dialokasikan untuk jembatan dan jalan $\mathrm{Rp} 4,7$ triliun, untuk pengairan irigasi Rp600 miliar, untuk sanitasi dan air minum Rp400 miliar dan untuk perumahan 
Rp300 miliar. Direncanakan pada tahun 2017 akan dimulai proyek pembangunan kereta api sebagai sarana transportasi. Pembanguan infrastruktur, sarana dan prasana yang memadai di Papua ini selain akan berdampak pada pertumbuhan perekonomian, juga diharapkan akan berdampak pada pemerataan kesejahteraan untuk masyarakat Papua.

Peningkatan realisasi nilai investasi selama lima tahun belakangan ternyata diikuti dengan peningkatan kesejahteraan masyarakat yang digambarkan oleh angka Indeks Pembangunan Manusia (IPM). Nilai indeks ditahun 2011 yaitu 67,09 mengalami kenaikan sebesar 2. 46 poin menjadi 69.55 pada tahun 2016. seperti yang ditunjukkan pada Tabel 1. Namun dari data diketahui bahwa laju pertumbuhan tidak mengalami peningkatan seperti halnya dalam investasi. Pada tahun 2011 laju pertumbuhan PDRB atas dasar harga konstan 2010 sebesar 6,16\% dan pada tahun 2015 turun sebesar $1,18 \%$ menjadi $4,98 \%$. Berbeda dengan nilai IPM yang terus mengalami kenaikan, dari 67,09 pada tahun 2011 naik menjadi 69. 55 di tahun 2015. Tujuan penelitian ini untuk memberikan bukti empiris pada pengaruh

Tabel 1

Indeks Pembangunan Manusia Indonesia per Provinsi, 2011-2015

\begin{tabular}{|c|c|c|c|c|c|c|}
\hline NO & PROVINSI & 2011 & 2012 & 2013 & 2014 & 2015 \\
\hline 1 & Aceh & 67.45 & 67.81 & 68.30 & 68.81 & 69.45 \\
\hline 2 & Sumatera Utara & 67.34 & 67.74 & 68.36 & 68.87 & 69.51 \\
\hline 3 & Sumatera Barat & 67.81 & 68.36 & 68.91 & 69.36 & 69.98 \\
\hline 4 & Riau & 68.90 & 69.15 & 69.91 & 70.33 & 70.84 \\
\hline 5 & Jambi & 66.14 & 66.94 & 67.76 & 68.24 & 68.89 \\
\hline 6 & Sumatera Selatan & 65.12 & 65.79 & 66.16 & 66.75 & 67.46 \\
\hline 7 & Bengkulu & 65.96 & 66.61 & 67.50 & 68.06 & 68.59 \\
\hline 8 & Lampung & 64.20 & 64.87 & 65.73 & 66.42 & 66.95 \\
\hline 9 & Kep. Bangka Belitung & 66.59 & 67.21 & 67.92 & 68.27 & 69.05 \\
\hline 10 & Kepulauan Riau & 71.61 & 72.36 & 73.02 & 73.40 & 73.75 \\
\hline 11 & D.K.I Jakarta & 76.98 & 77.53 & 78.08 & 78.39 & 78.99 \\
\hline 12 & Jawa Barat & 66.67 & 67.32 & 68.25 & 68.80 & 69.50 \\
\hline 13 & Jawa Tengah & 66.64 & 67.21 & 68.02 & 68.78 & 69.49 \\
\hline 14 & D.I. Yogyakarta & 75.93 & 76.15 & 76.44 & 76.81 & 77.59 \\
\hline 15 & Jawa Timur & 66.06 & 66.74 & 67.55 & 68.14 & 68.95 \\
\hline 16 & Banten & 68.22 & 68.92 & 69.47 & 69.89 & 70.27 \\
\hline 17 & Bali & 70.87 & 71.62 & 72.09 & 72.48 & 73.27 \\
\hline 18 & Nusa Tenggara Barat & 62.14 & 62.98 & 63.76 & 64.31 & 65.19 \\
\hline 19 & Nusa Tenggara Timur & 60.24 & 60.81 & 61.68 & 62.26 & 62.67 \\
\hline 20 & Kalimantan Barat & 62.35 & 63.41 & 64.30 & 64.89 & 65.59 \\
\hline 21 & Kalimantan Tengah & 66.38 & 66.66 & 67.41 & 67.77 & 68.53 \\
\hline 22 & Kalimantan Selatan & 65.89 & 66.68 & 67.17 & 67.63 & 68.38 \\
\hline 23 & Kalimantan Timur & 72.02 & 72.62 & 73.21 & 73.82 & 74.17 \\
\hline 24 & Kalimantan Utara & - & - & 67.99 & 68.64 & 68.76 \\
\hline 25 & Sulawesi Utara & 68.31 & 69.04 & 69.49 & 69.96 & 70.39 \\
\hline 26 & Sulawesi Tengah & 64.27 & 65.00 & 65.79 & 66.43 & 66.76 \\
\hline 27 & Sulawesi Selatan & 66.65 & 67.26 & 67.92 & 68.49 & 69.15 \\
\hline 28 & Sulawesi Tenggara & 66.52 & 67.07 & 67.55 & 68.07 & 68.75 \\
\hline 29 & Gorontalo & 63.48 & 64.16 & 64.70 & 65.17 & 65.86 \\
\hline 30 & Sulawesi Barat & 60.63 & 61.01 & 61.53 & 62.24 & 62.96 \\
\hline 31 & Maluku & 64.75 & 65.43 & 66.09 & 66.74 & 67.05 \\
\hline 32 & Maluku Utara & 63.19 & 63.93 & 64.78 & 65.18 & 65.91 \\
\hline 33 & Papua Barat & 59.90 & 60.30 & 60.91 & 61.28 & 61.73 \\
\hline \multirow[t]{2}{*}{34} & Papua & 55.01 & 55.55 & 56.25 & 56.75 & 57.25 \\
\hline & Indonesia & 67.09 & 67.70 & 68.31 & 68.90 & 69.55 \\
\hline
\end{tabular}

Sumber: BPS DKI Jakarta 


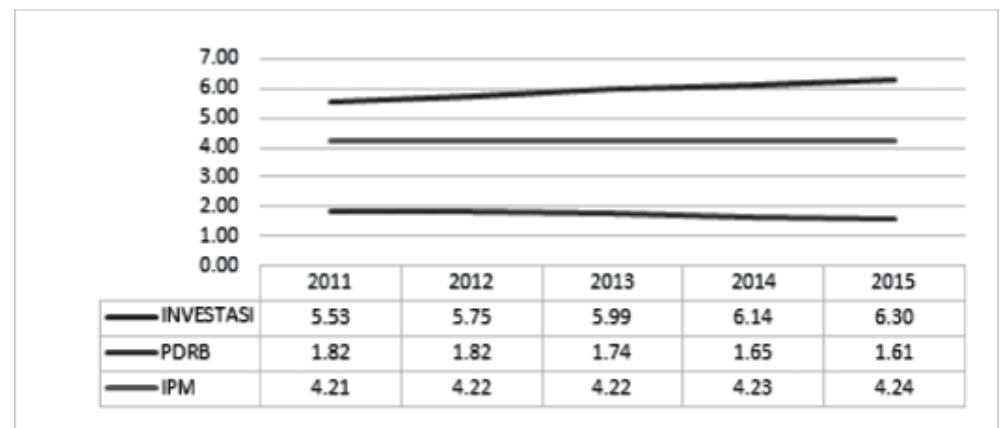

Sumber: Data diolah, 2016

belanja modal terhadap pertumbuhan ekonomi; pengaruh investasi swasta terhadap pertumbuhan ekonomi; dan pengaruh pertumbuhan ekonomi terhadap kesejahteraan masyarakat.

\section{METODE PENELITIAN}

Untuk meningkatkan output nasional diperlukan investasi baik dari sektor pemerintah maupun sector swasta. Aktivitas investasi ini akan mendorong tingkat produksi ketingkat yang optimum dan memberikan kontribusi pada tingkat output. Kegiatan investasi pemerintah tercermin dalam ketersediaan infrastrukturn yang didanai oleh belanja modal pemerintah seperti pembangunan jalan, listrik, sanitasi, irigasi, telekomunikasi dan yang lainnya. Penelitian Muthui et. al. (2013), Nurmainah (2013) menyimpulkan bahwa alokasi belanja pemerintah untuk infrastruktur berdampak positif dan signifikan terhadap pertumbuhan ekonomi dan didukung oleh penelitian Maryaningsih et.al. (2014) mempertegas bahwa ketersediaan infrastruktur yang memadai termasuk ketersediaan listrik, transportasi darat dan laut menjadi faktor yang paling

dibutuhkan untuk mencapai pertumbuhan ekonomi yang berkesinmbungan.

Berdasar uraian tersebut, maka dibentuklah hipotesis sebagai berikut:

H1: Belanja Modal berpengaruh positif terhadap Pertumbuhan Ekonomi.

H2: Investasi Swasta berpengaruh positif terhadap Pertumbuhan Ekonomi.
Kesejahteraan masyarakat merupakan kondisi apabila terpenuhi kebutuhan dasar hidup, seperti rumah yang layak, kebutuhan sandang dan pangan yang cukup, biaya pendidikan dan kesehatan yang murah dan berkualitas. Indeks Pembangunan Manusia (IPM) memberikan sudut pandang yang lebih luas untuk menilai tingkat kesejahteraan manusia. IPM menggambarkan kesejahteraan manusia dalam tiga dimensi, yaitu pendidikan, kesehatan dan daya beli. Pertumbuhan ekonomi per kapita mengindikasikan daya beli individu. Apabila daya beli individu

meningkat maka kemampuan

individu untuk memenuhi kebutuhan standar hidupnya juga akan meningkat. Sehingga cara terbaik untuk meningkatkan kesejahteraan masyarakat adalah dengan memaksimalkan pertumbuhan ekonomi. Hal ini sejalan dengan hasil penelitian Algifari (2011). Berdasar uraian tersebut, maka dibentuklah hipotesis sebagai berikut:

H3: Pertumbuhan Ekonomi berpengaruh positif terhadap kesejahteraan masyarakat.

Kerangka befikir tersebut dapat diringkas dalam sebuah tabel 2 .

Wijaya (2013:27) menyebutkan populasi adalah seluruh kumpulan elemen (orang, kejadian, produk) yang dapat digunakan untuk membuat beberapa kesimpulan. Dengan kata lain, populasi terdiri dari sekumpulan objek atau subjek yang memiliki kualitas dan karakteristik khusus yang ditentukan untuk diteliti. Sedangkan 
Tabel 2

Kerangka Berfikir

\begin{tabular}{|c|c|}
\hline Hipotesis & Argumen \\
\hline $\begin{array}{l}\text { H1: } \\
\text { Belanja Modal berpengaruh positif } \\
\text { terhadap Pertumbuhan Ekonomi. }\end{array}$ & $\begin{array}{l}\text { Belanja modal merupakan pengeluaran pemerintah yang } \\
\text { dianggarkan untuk tujuan pembangunan infrastruktur. } \\
\text { Apabila infrastruktur yang memadai tersedia, maka } \\
\text { dapat mendorong produksi mencapai output yang diten- } \\
\text { tukan, selanjutnya meningkatkan pertumbuhan ekonomi. } \\
\text { Semakin besar anggaran belanja modal pemerintah, be- } \\
\text { rarti semakin besar kontribusinya dalam meningkatkan } \\
\text { pertumbuhan ekonomi. } \\
\text { Seperti teori Wagner, menyatakan bahwa ada hubungan } \\
\text { positif antara belanja pemerintah terhadap tingkat per- } \\
\text { tumbuhan ekonomi. }\end{array}$ \\
\hline $\begin{array}{l}\mathrm{H} 2: \\
\text { Investasi Swasta berpengaruh positif } \\
\text { terhadap Pertumbuhan Ekonomi. }\end{array}$ & $\begin{array}{l}\text { Investasi dapat tercapai apabila terdapat akumulasi mod- } \\
\text { al. Investasi sektor swasta menyebabkan tersedianya ba- } \\
\text { rang-barang modal yang siap digunakan dalam produksi. } \\
\text { Selanjutnya peningkatan kapasitas produksi mendorong } \\
\text { laju pertumbuhan ekonomi. }\end{array}$ \\
\hline $\begin{array}{l}\text { H3: } \\
\text { Pertumbuhan Ekonomi berpengaruh } \\
\text { positif terhadap Kesejahteraan Ma- } \\
\text { syarakat. }\end{array}$ & $\begin{array}{l}\text { Pertumbuhan ekonomi mencerminkan pendapatan per } \\
\text { kapita. Pendapatan per kapita menggambarkan daya beli } \\
\text { masyarakat. Apabila daya beli masyarakat meningkat, } \\
\text { maka masyarakat akan memaksimalkan pendapatannya } \\
\text { untuk memenuhi kebutuhan dasar hidup yang mencakup } \\
\text { tiga dimensi, yaitu dimensi pendidikan, kesehatan dan } \\
\text { pendapatan. }\end{array}$ \\
\hline
\end{tabular}

sampel merupakan bagian dari populasi yang digunakan oleh peneliti untuk diteliti yang dianggap sudah mewakili populasi berdasarkan karakteristik dan teknik tertentu.

Dalam pemilihan waktu penelitian, menggunakan data dari tahun 2010 sampai dengan tahun 2015. Penentuan tahun 2010 mengacu pada tahun penerapan metode baru perhitungan IPM yang digunakan oleh Badan Pusat Statistik (BPS). Adapun pertimbangan BPS menggunakan metode baru adalah dikarenakan indikator angka melek huruf sudah tidak tepat untuk digunakan dalam penghitungan IPM. Angka melek huruf tidak dapat menggambarkan kualitas pendidikan

yang ada saat ini, sebab sebagian besar daerah di Indonesia sudah memiliki angka melek huruf yang tinggi sehingga tidak dapat membedakan tingkat pendidikan antar daerah dengan baik dan tidak relevan dalam mengukur pendidikan secara utuh. Selain itu, penggunaan rumus rata-rata aritmatik dalam penghitungan IPM menggambarkan bahwa capaian yang rendah di suatu dimensi dapat ditutupi oleh capaian tinggi dari dimensi lain. Selanjutnya penentuan tahun 2015 sebagai tahun akhir penelitian dikarenakan ketersediaan data pada saat penelitian dilakukan baru tersedia hingga tahun 2016.
Kriteria yang digunakan dalam pengambilan sampel pada penelitian ini adalah seluruh kabupaten/kota di Indonesia yang menyediakan data belanja modal, penanaman modal asing \& penanaman modal dalam negeri, produk domestik regional bruto dan indeks pembangunan manusia mulai dari tahun 2010 sampai dengan tahun 2015, kecuali untuk DKI Jakarta. Pengecualian tersebut dilakukan karena wilayah kota dan kabupaten di DKI Jakarta bukanlah daerah otonom. Jenis data yang digunakan pada penelitian ini adalah data sekunder. Data sekunder adalah data yang diperoleh dari sumber yang menerbitkan dan bersifat siap pakai. Sedangkan sumber data yang digunakan pada penelitian ini diperoleh dari Badan Pusat Statistik (BPS) melalui situs www. bps.go.id, Direktorat Jenderal Perimbangan Keuangan Kementrian Keuangan melalui situs http://www.djpk.depkeu.go.id dan Badan Koordinasi Penanaman Modal melalui situs www.bkpm.go.id. Untuk belanja modal, investasi swasta dan pertumbuhan ekonomi, sebelum diolah dengan WarpPLS terlebih dahulu dilakukan logaritma natural. Pertumbuhan ekonomi yang digunakan pada penelitian ini menggunakan data menurut harga konstan 2010.

Belanja modal yang digunakan pada penelitian ini adalah realisasi belanja modal 
pemerintah. Angka realisasi belanja modal pemerintah yang digunakan merujuk pada akun belanja modal yang terdapat dalam laporan tahunan realisasi pengeluaran pemerintah kabupaten/kota menurut klasifikasi jenis pengeluaran dalam satuan mata uang rupiah yang diperoleh dari situs resmi Badan Pusat Statistik. Sebelum mengolah data, terlebih dahulu dilakukan logaritma natural (In) atas angka belanja modal yang digunakan. Angka hasil logaritma natural tersebutlah yang digunakan dalam pengolahan data.

Investasi swasta yang digunakan dalam penelitian ini merupakan gabungan antara nilai realisasi Penanaman Modal Dalam Negeri (PMDN) dan Penanaman Modal Asing (PMA). Angka realisasi PMDN dan PMA diperoleh dari situs resmi Badan Kordinasi Penanaman Modal. Sebelum pengolahan data dilakukan, karena PMA masih dalam satuan mata uang dolar Amerika (US\$), maka pertama-tama harus dilakukan konversi nilai PMA ke dalam mata uang rupiah. Konversi ini menggunakan kurs rupiah pada tanggal 31 Desember setiap tahunnya yang diterbitkan oleh Bank Indonesia, sehingga dapat dijumlahkan dengan nilai PMDN. Selanjutnya, karena nilai penjumlahan tersebut cukup besar, maka dilakukan logaritma natural (In) terhadap nilai investasi swasta tersebut. Hasil dari logaritma ntural tersebutlah yang digunakan dalam pengolahan data.

Menurut Badan Pusat Statistik, Produk Domestik Bruto (PDB) pada dasarnya merupakan jumlah nilai tambah yang dihasilkan oleh seluruh unit usaha dalam suatu negara tertentu, atau merupakan jumlah nilai barang dan jasa akhir yang dihasilkan oleh seluruh unit ekonomi, sehingga untuk mengetahui kondisi ekonomi di suatu negara dalam suatu periode tertentu yang digunakan adalah data PDB. Terdapat dua jenis PDB, yaitu atas dasasr harga berlaku dan atas dasar harga konstan. PDB atas dasar harga berlaku menggambarkan nilai tambah barang dan jasa yang dihitung menggunakan harga yang berlaku pada setiap tahun, sedangkan PDB atas dasar harga konstan menunjukkan nilai tambah barang dan jasa tersebut yang dihitung menggunakan harga yang

berlaku pada satu tahun tertentu sebagai dasar. Pertumbuhan ekonomi yang digunakan pada penelitian ini merujuk kepada angka Produk Domestik Regional Bruto (PDRB) atas dasar harga konstan 2010 yang terdapat pada publikasi terbitan Badan Pusat Statistik dalam satuan mata uang rupiah, karena PDB atas dasar harga berlaku, digunakan untuk melihat pergeseran dan struktur ekonomi. Sebelum mengolah data, terlebih dahulu dilakukan logaritma natural (In) terhadap angka PDRB yang digunakan. Angka hasil logaritma natural tersebutlah yang digunakan dalam pengolahan data.

Todaro \& Smith (2015:114) menyebutkan bahwa indikator yang lebih baik untuk mengukur kesenjangan dan ukuran pembangunan adalah dengan memasukkan aspek kesehatan, aspek pendidikan dalam memperhitungkan kesejahteraan masyarakat, bukan sekedar mengacu pada tingkat pendapatan, dan Indeks Pembangunan Manusia (Human Development Index, HDI) dapat digunakan untuk melakukan perhitungan tersebut.

Badrudin (2012:149) menyebutkan bahwa indicator kesejahteraan masyarakat terkini adalah IPM. Lebih jauh, Badan Pusat Statistik (BPS) menjelaskanIPM merupakan ukuran capaian pembanguan manusia berbasis sejumlah komponen dasar kualitas hidup. IPM dibentuk dengan pendekatan tiga dimensi dasar, yaitu umur panjang \& sehat, pengetahuan dan kehidupan

yang layak. Oleh karenaitu, kesejahteraan masyarakat yang digunakan dalam dalam penelitian ini diukur dengan Indeks Pembanguan Manusia yang diterbitkan oleh BPS pada situs resminya. Untuk kesesragaman, sebelum mengolah data terlebih dahulu dilakukan logaritma natural (In) terhadap angka IPM yang digunakan. 
Angka hasil logaritma natural tersebutlah yang digunakan dalam pengolahan data.

Pada penelititan ini peneliti ingin mengetahui kompleksitas hubungan antara konstrak yang satu dengan konstrak yang lain serta hubungan suatu konstrak dengan indikator-indikatornya, sehingga peneliti memilih untuk menggunakan metode Partial Least Square (PLS) dengan alat analisis WarpPLS versi 4,0 . PLS dibentuk oleh dua persamaan, yaitu inner model dan outter model. Inner model menjelaskan hubungan antara konstrak yang satu dengan konstrak yang lainnya, sedangkan outer model menjelaskan hubungan antara konstrak dengan indikator-indikatornya. Konstrak itu sendiri pada PLS terbagi menjadi dua, yaitu konstrak eksogen dan konstrak endogen. Juliandi dkk (2014:166-167) menjelaskan dua variabel tersebut sebagai berikut, yaitu
Variabel endogen intervening dalam penelitian ini adalah Pertumbuhan Ekonomi (n1). Variabel endogen terikat adalah variabel yang dipengaruhi oleh variabel eksogen maupun variable endogen interving. Variabel endogen terikat dalam penelitian ini adalah Kesejahteraan Masyarakat (n2).

\section{HASIL PENELITIAN}

Populasi dalam penelitian ini adalah seluruh kabupaten/ kota yang ada di Indonesia. Sejak tahun 1999 hingga tahun 2014 pertambahan daerah otonom di Indonesia terus meningkat. Menurut catatan Dirjen Otonomi Daerah Kementerian Dalam Negeri yang diperoleh dari situs resmi kementrian dalam negeri, selama tahun 1999 sampai tahun 2004 terdapat penambahan daerah otonom 7 provinsi, 115 kabupaten dan 26 kota. Dan antara tahun 2005 sampai

Tabel 3

Perkembangan Daerah Otonomi Baru

\begin{tabular}{lccc}
\hline \multicolumn{1}{c}{ Keterangan } & $\mathbf{1 9 9 8}$ & $\mathbf{2 0 0 4}$ & $\mathbf{2 0 1 4}$ \\
\hline Jumlah Provinsi & 26 & 33 & 34 \\
Jumlah Kabupaten Otonomi & 233 & 348 & 415 \\
Jumlah Kota Otonom & 60 & 86 & 93 \\
\hline Sumber: http://otda.kemendagri.go.id/NewsOTDA
\end{tabular}

1) variabel eksogen adalah variable yang memengaruhi atau menjadi penyebab dalam suatu model penelitian. Variabel eksogen dapat disebut juga variabel yang selalu berperan sebagai variabel bebas. Variabel eksgoen dalam penelitian ini adalah Belanja Modal (X1) dan Investasi Swasta (X2) dan 2) variabel endogen adalah variabel yang dipengaruhi atau menjadi dampak dalam suatu model penelitian atau disebut juga sebagai variabel ganda karena dapat berfungsi sebagai variabel bebas, variabel terikat atau variabel intervening. Variabel endogen intervening adalah variabel yang ikut berpengaruh saat variabel eksogen memengaruhi variabel endogen terikat. tahun 2014 penambahan daerah otonom sebanyak 1 provinsi, 67 kabupaten dan 7 kota.

Penentuan sampel menggunakan metode purposive sampling sehingga sampel yang digunakan hanyalah yang memenuhi kriteria dalam penelititan ini. Kabupaten/kota pada penelitian ini sebanyak 508 kabupaten/kota dengan waktu penelitian enam tahun dari tahun 2010 sampai dengan 2015, maka total populasi sebanyak 3.048. Data kabupaten/ kota yang tidak memenuhi kriteria untuk dijadikan sampel sebanyak 1.165 , sehingga sampel yang dapat digunakan adalah 1.883. 


\section{Tabel 4}

\begin{tabular}{clc}
\hline No & \multicolumn{1}{c}{ Keterangan } & Jumlah \\
\hline 1 & $\begin{array}{l}\text { Jumlah kabupaten/kota di Indonesia sampai dengan Desember } \\
\text { 2014 sebanyak 508 dengan periode 6 tahun (2010- 2015) }\end{array}$ & 3.048 \\
2 & $\begin{array}{l}\text { Kabupaten/kota yang tidak menyajikan data untuk pengukuran } \\
\text { variabel sampel }\end{array}$ & 1.165 \\
3 & Jumlah sampel yang digunakan dalam penelitian & 1.883 \\
\hline
\end{tabular}

Sumber: Data diolah, 2016

Tercatat 508 kabupaten/kota di Indonesia sampai dengan Desember 2014. Dengan teknik purposive sampling maka populasi sebanyak 3.048 dengan 508 kabupaten/kota yang memenuhi kriteria selama periode 2010-2015 adalah sebanyak 1.883.

\section{Populasi dan Sampel}

Untuk mempermudah membaca dan memahami data yang digunakan, maka diberikan gambaran statistik yang mencakup mean, nilai maksimum, nilai minimum serta standar deviasi dari masing-masing variabel. Nilai mean adalah cara yang dapat menggambarkan nilai sentral dari distribusi data, nilai maksimum digunakan untuk menunjukkan nilai tertinggi dari data yang digunakan. Demikian juga dengan nilai minimun, menunjukkan nilai terendah dari data dan standar deviasi menunjukkan seberapa besar penyimpangan atau variasi dari setiap variabel terhadap nilai mean. Variabel yang digunakan dalam penelitian ini adalah belanja modal, investasi swasta, pertumbuhan ekonomi dan kesejahteraan masyarkat dan hasil statistic deskriptif dari variabel-variabel tersebut dapat dilihat pada Tabel berikut: dalam Laporan Realisasi Anggaran (LRA) setiap tahun. Berdasar data yang diolah, diketahui bahwa total nilai realisasi belanja modal selama periode 2010-2015 adalah Rp508.456.187.245. Nilai belanja modal meningkat sebesar Rp467.255.406.965 bila dibandingkan pada tahun 2010 sebesar Rp41.200.780.280 menjadi Rp129.046.359.725 pada tahun 2015.

\section{Realisasi Belanja Modal}

Berdasar data didapati sebanyak $70 \%$ kabupaten/ kota yang berada di bawah rata-rata yaitu 1.326 kabupaten/ kota dengan total nilai realisasi sebesar Rp202.277.691.038, dan sisanya sebanyak 557 kabupaten/ kota berada di atas nilai rata-rata dengan total nilai realisasi belanja modal sebesar Rp 306.178.496.207. Realisasi belanja modal tertinggi untuk periode tahun 2010 sampai dengan tahun 2015 sebesar Rp4.750.206.918

Tabel 5

Realisasi Belanja Modal Kabupaten/Kota Di Indonesia (dalam jutaan rupiah)

\begin{tabular}{|c|c|c|c|c|c|c|}
\hline & 2010 & 2011 & 2012 & 2013 & 2014 & 2015 \\
\hline Total Nilai & 41,201 & 53,334 & 71,906 & 97,179 & 115,790 & 29,046 \\
\hline Nilai Tertinggi & 1,272 & 1,258 & 1,819 & 3,416 & 4,750 & 2,597 \\
\hline Nilai Terendah & 21 & 49 & 55 & 56 & 70 & 46 \\
\hline Rata-rata & 165 & 186 & 241 & 299 & 330 & 346 \\
\hline Standar Deviasi & 151 & 140 & 206 & 296 & 361 & 311 \\
\hline
\end{tabular}

Mengukur variabel belanja modal didapatkan dari nilai realisasi pengeluaran pemerintah pada akun belanja modal di Kabupaten Tangerang Selatan pada tahun 2014, diikuti oleh Kabupaten Kutai Kartanegara dengan nilai realisasi belanja 


\section{Gambar 3}

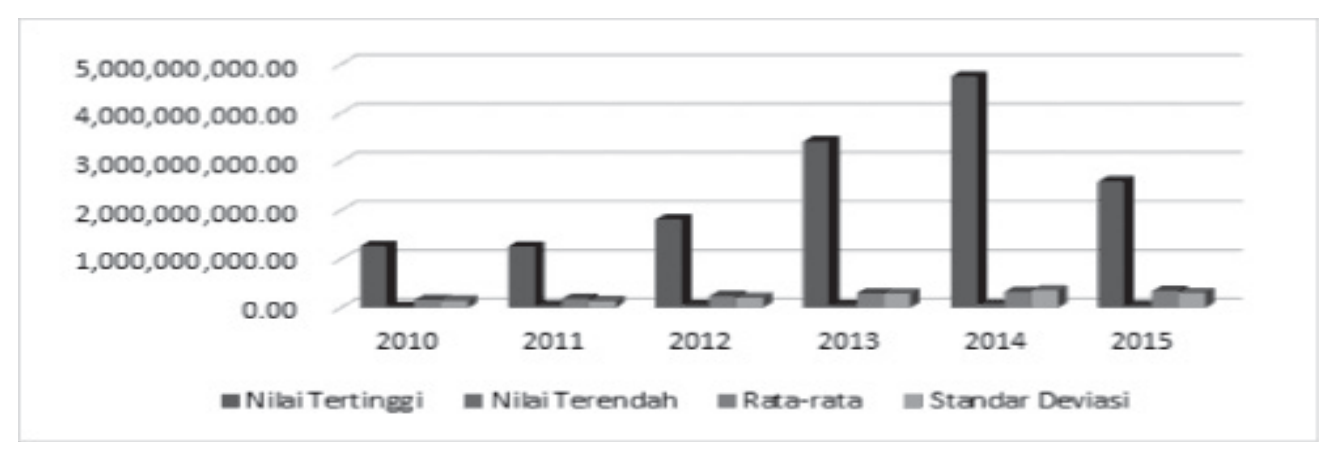

Sumber: Data diolah, 2016

modal sebesar Rp3.416.042.298 pada tahun 2013 dan Rp2.597.203.595 pada tahun 2015. Sementara ratarata realisasi belanja modal untuk periode tersebut adalah Rp270.024.529 dengan besaran standar deviasi yang sedikit di atas nilai rata-rata yaitu sebesar Rp275.265.491. Artinya nilai realisasi belanja modal agak bervariasi. Sementara untuk tiga nilai realisasi belanja modal terendah berada pada kabupaten Blora sebesar Rp21.200.833 pada tahun 2010, diikuti oleh kabupaten Batang sebesar
2010 sampai dengan tahun 2015 mencapai nilai Rp2.000.233.964.647.900 dengan realisasi tertinggi terdapat di kabupaten Karawang pada tahun 2013 sebesar Rp47.591.240.900.000, kemudian diikuti oleh kabupaten Bekasi dengan nilai pencapaian Rp36.147.487.368.000 pada tahun 2015 dan pada tahun 2014 sebesar Rp31.589.287.677.200. Realisasi terendah berada pada kota Tual dengan nilai pencapaian sebesar $\mathrm{Rp} 1.386 .400$ pada tahun 2015, selanjutnya realisasi

\section{Tabel 6}

Realisasi Investasi Swasta Kabupaten/Kota di Indonesia (dalam milyar rupiah)

\begin{tabular}{lrrrrrr}
\hline & \multicolumn{1}{c}{$\mathbf{2 0 1 0}$} & \multicolumn{1}{c}{$\mathbf{2 0 1 1}$} & \multicolumn{1}{c}{$\mathbf{2 0 1 2}$} & \multicolumn{1}{c}{$\mathbf{2 0 1 3}$} & $\mathbf{2 0 1 4}$ & \multicolumn{1}{c}{$\mathbf{2 0 1 5}$} \\
\hline Total Nilai & $39,105,543$ & $96,050,094$ & $79,711,826$ & $38,931,778$ & $34,615,253$ & $11,819,471$ \\
Nilai Tertinggi & $10,097,837$ & $15,080,894$ & $19,758,156$ & $47,591,241$ & $31,589,288$ & $36,147,487$ \\
Nilai Terendah & 24.40 & 16.40 & 5.70 & 2.45 & 3.75 & 1.39 \\
Rata-rata & 556,422 & 685,490 & 938,630 & $1,350,559$ & $1,238,220$ & $1,372,170$ \\
Standar Deviasi & $1,341,192$ & $1,641,470$ & $2,318,225$ & $4,253,306$ & $3,112,956$ & $3,489,494$ \\
\hline
\end{tabular}

Sumber: Data diolah, 2016

Rp25.478.767 pada tahun 2010 dan terakhir ditunjukkan oleh kabupaten Ogan Ilir sebesar Rp27.008.763 ditahun 2010.

Variabel investasi swasta diukur dengan menjumlahkan total realisasi penanaman modal dalam negeri dan penanaman modal asing per tahun. Dari data dapat diketahui bahwa realisasi investasi swasta selama periode tahun terendah kedua berada pada kabupaten Padang Lawas pada tahun 2013 sebesar Rp2.450.000 dan terendah ketiga berada di kabupaten Bima pada tahun 2014 sebesar Rp3.750.600.

Selanjutnya rata-rata nilai investasi di kabupaten/ kota selama tahun 2010 sampai dengan tahun 2015 adalah sebesar Rp1.023.581.978.752 dengan besaran 
standar deviasi Rp1.124.177.504.084 yang lebih besar dari nilai rata-rata. Ini berarti bahwa data variabel investasi swasta cukup bervariasi. Dari 1.883 data realisasi investasi swasta di kabupaten/kota ditemukan $79 \%$ atau sebanyak 1.495 kabupaten/kota yang nilai realisasi investasi swastanya kabupaten/kota yang pencapaian PDRBnya di bawah rata-rata, dengan total sebesar Rp14.644.332 milyar, dan sisanya sebesar $27 \%$ atau sebanyak 506 kabupaten/ kota yang pencapaian PDRBnya lebih besar dari ratarata dengan total keseluruhan sebesar Rp19.901.338 milyar.

Tabel 8

Indeks Pembangunan Manusia Kabupaten/Kota di Indonesia

\begin{tabular}{|c|c|c|c|c|c|c|}
\hline & 2010 & 2011 & 2012 & 2013 & 2014 & 2015 \\
\hline Nilai Tertinggi & 82.72 & 82.98 & 83.29 & 83.61 & 83.78 & 84.56 \\
\hline Nilai Terendah & 52.57 & 45.82 & 55.28 & 45.68 & 39.68 & 49.77 \\
\hline Rata-rata & 65.63 & 66.05 & 66.46 & 67.10 & 67.54 & 68.22 \\
\hline Standar Deviasi & 5.61 & 5.56 & 5.29 & 5.55 & 5.69 & 5.47 \\
\hline
\end{tabular}

Sumber: Data diolah, 2016

berada di bawa rata-rata dengan total Rp603.092.806.159, sedangkan sisanya sebesar $21 \%$ lagi yaitu 388 kabupaten/kota nilai realisasi investasi swastanya berada di atas nilai rata-rata dengan total $\mathrm{Rp}$ 1.397.141.158.488.300.

Selama periode tersebut, Kota Surabaya didapati memiliki tingkat PDRB tertinggi yaitu Rp324.228 milyar, Rp305.957 milyar, Rp286.051 milyar, Rp265.892 milyar, Rp247.687 milyar dan Rp231.205 milyar pada tahun 2015, 2014, 2013, 2012, 2011 dan 2010 secara berurut. Sedangkan kabupaten/kota dengan tingkat PDRB terendah adalah kabupaten Pegunungan Arfak pada tahun 2015 sebesar Rp112 juta, kabupaten Tambrauw pada tahun 2014 sebesar Rp113 juta dan kabupaten Tambrauw sebesar Rp120 juta pada tahun 2015. Rata-rata pencapain PDRB selama periode tersebut sebesar Rp18.289.737.391.293 dengan besaran standar deviasi Rp1.482.717.879.940. Angka standar deviasi berada di bawah angka rata-rata menunjukkan bahwa terdapat PDRB tidak bervariasi.Dari data, didapati sebesar $73 \%$ atau sebanyak 1.377
Pengukuran variabel berikutnya adalah variable kesejahteraan masyarakat yang diukur dengan menggunakan angka Indeks Pembangunan Manusia (IPM) yang diterbitkan oleh Badan pusat Statistik (BPS). Kota Yogyakarta tercatat memiliki pencapain IPM tertinggi selama tahun 2010 sampai tahun 2015 yaitu $84,56,83,78,83,61,83,29$, 82,98 dan 82,72 secara berurut

Sedangkan pencapaian IPM terendah ditunjukkan oleh kabupaten Pegunungan Bintang pada tahun 2014 dengan angka indeks 39.68, diikuti oleh kabupaten Tolikara pada tahun 2013 dengan angka indeks 45,68 kemudian kabupaten Mamberamo Raya pada tahun 2011 dengan angka indeks 45,82 . Rata-rata pencapain IPM adalah 66,83 dengan besaran standar deviasi lebih rendah dari rata-rata, yaitu 5.59 yang berarti pencapaian IPM di kabupaten/kota di Indonesia tidak terlalu bervariasi. Model fit indices merupakan ukuran yang sangat penting dalam pengolahan data dengan WarpPLS karena fit indices menunjukkan kesesuaian model dengan data serta menunjukkan kualitas dari model yang diteliti. Kriterianya yaitu nilai $p$-value APC 


\section{Tabel 9}

\section{Model Fit and Quality Indices}

\begin{tabular}{ll}
\hline APC $=0,418 ; P<0,001$ & Good if $P<0,05$ \\
\hline ARS $=0,339 ; P<0,001$ & Good if $P<0,05$ \\
\hline AVIF $=1,339$ & acceptable if $<=5$, ideally $<=3,3$ \\
\hline
\end{tabular}

dan ARS $<0.05$ dan AVIF $<5$ sehingga model fit dengan data. Dari pengolahan data dengan menggunakan variable belanja modal, investasi swasta, pertumbuhan ekonomidan kesejahteraan masyarakat, diperoleh nilai APC, ARS dan AVIF seperti pada tabel.

Berdasar Tabel 9, terlihat bahwa antara variable eksogen dan endogen memiliki hubungan sebab akibat baik secara langsung maupun tidak langsungyang dicerminkan oleh $P$-value average path coefficient (APC) yang signifikan $P<0,001$ (signifikan bila $\mathrm{P}<0,05$ ). Nilai average $R$-squared (ARS) menunjukkan hasil yang signifikan dengan nilai 0,339 , artinya bahwa pengaruh variabel eksongen terhadap variable endogen hanya sebesar $33,9 \%$, sisanya sebesar $66,1 \%$ dipengaruhi oleh faktor-faktor lain di luar model. Hasil average varian inflation factor (AVIF) sebesar 1,339 dapat diterima karena nilai AVIF yang ditentukan adalah $\mathrm{AVIF}<=5$, yang berarti bahwa tidak terdapat multikolinearitas antar variabel dalam model penelitian ini sehingga model penelitian ini dapat digunakan untuk memprediksi pengaruh variabel eksogen terhadap variabel endogen.

\section{PEMBAHASAN}

Berdasarkan teori-teori, penelitian terdahulu telah disusun hipotesis pada penelitian ini yang menguji pengaruh belanja modal dan investasi swasta terhadap pertumbuhan ekonomi serta dampaknya pada kesejahteraan masyarakat. Berdasar tiga hipotesis yang disusun, diperoleh hasil pengujian datanya seperti yang ditampilkan pada Tabel 10.
Banyak pandangan yang menyebutkan bahwa keterlibatan pemerintah dalam perekonomian adalah bersifat pro growth, yang artinya dapat merangsang pertumbuhan ekonomi suatu negara. Teori ekonomi makro juga menjelaskan bahwa peningkatan output dalam perekonomian dipengaruhi oleh belanja pemerintah dan investasi. Pembangunan infrastruktur yang didanai dari belanja pemerintah telah meningkatkan pertumbuhan ekonomi di beberapa daerah di Indonesia, seperti pembangunan jalan tol di Papua, merangsang kegiatan ekonomi lebih tinggi karena telah membuka akses yang lebih baik sehingga jalur logistik di daerah Papua yang selama ini tersendat, perlahan-lahan mulai berkurang. Demikian juga halnya dengan pembangunan tol Cipali, memberi dampak pada perekonomian daerah-daerah sekitarnya. Jumlah pariwisata meningkat dikarenaka akses jalan yang sudah lebih baik, pembangunan hotel-hotel pun meningkat. Jelaslah bahwa belanja modal memberi kontribusi pada perekonomian untuk meningkatkan output. Banyak penelitian terdahulu menunjukkan bahwa belanja modal berpengaruh positif terhadap peningkatan output dalam perekonomian. Artinya, semakin tinggi belanja modal yang terealisasi, maka semakin tinggi pula output yang dihasilkan.

Hasil pengujian terhadap hipotesis pertama, yaitu belanja modal berpengaruh positif terhadap pertumbuhan ekonomi menghasilkan nilai yang signifikan seperti yang ditunjukkan oleh $P$-value $<0,001$, lebih kecil dari nilai $P$-value yang ditetapkan $(\leq 0,05)$. Hasil koefisien jalur 0,411 bertanda 
positif sehingga hipotesis pertama diterima. Artinya apabila terjadi peningkatan pada jumlah belanja modal, maka pertumbuhan ekonomi juga akan meningkat. Hasil pengujian ini mendukung penelitian Fawwaz (2015), Maharani \&Isnowati (2014), Muthui et.al. (2013) dan Hendarmin (2012). Pembangunan infrastruktur yang dibiayai oleh anggaran pemerintah dalam belanja modal dapat meningkatkan aktivitas ekonomi masyarakat sehingga meningkatkan output barang dan jasa. Pembangunan infrastruktur di beberapa daerah yang saat ini masih minim seperti kebanyakan dibagian Timur Indonesia telah berhasil meningkatkan aktivitas ekonomi daerah tersebut.

Investasi swasta juga berkontribusi pada besaran output yang dihasilkan dalam suatu perekonomian. Todaro menguraikan teori pertumbuhan ekonomi Solow, disebutkan bahwa akumulasi modal yang digunakan untuk pengadaan faktor-faktor produksi baru atau untuk peningkatan kualitas faktor-faktor produksi dapat mempengaruhi pertumbuhan ekonomi. Kegiatan investasi swasta juga mempengaruhi kegiatan ekonomi serta kesempatan kerja sehingga meningkatkan pendapatan nasional yang pada akhirnya meningkatkan kesejahteraan masyarakat. Penelitian-penelitian terdahulu telah membuktikan bahwa peningkatan pada investasi swasta dapat meningkatkan pertumbuhan ekonomi suatu negara. Hasil pengujian statistik pada hipotesis kedua

diperoleh nilai $P$-value $<0,001$ yang berarti berpengaruh signifikan karena lebih kecil dari $P$-value yang ditetapkan $(\leq 0,05)$, nilai koefisien $\beta=0,329$ dengan slope positif, artinya semakin besar tingkat investasi swasta, berbanding lurus terhadap pertumbuhan ekonomi kabupaten/kota di Indonesia. Semakin besar jumlah investasi swasta, akan diikuti oleh pertumbuhan ekonomi yang semakin meningkat.

Dengan demikian hipotesis kedua yaitu, investasi swasta berpengaruh positif terhadap pertumbuhan ekonomi dapat diterima. Hasil ini sesuai dengan penelitian Puspitasari (2015), Sumanto (2015), Phesavsong (2012), Ramli (2011) yang menunjukkan bahwa investasi swasta berpengaruh positif dan signifikan terhadap pertumbuhan ekonomi. Peranan pihak swasta menginvestasikan modalnya di kabupaten/kota di Indonesia telah memberikan kesempatan kerja yang luas bagi masyarakat sehingga meningkatkan tingkat pendapatan masyarakat yang berdampak pada peningkatan nilai PDRB. Pembangunan ekonomi mendorong pertumbuhan ekonomi karena menigkatkan kegiatan ekonomi, membuka kesempatan kerja, yang berdampak pada peningkatan pendapatan masyarakat. Apabila pendapatan masyarakat meningkat, maka masyarakat dapat meningkatkan kualitas hidupnya dengan pemenuhan kebutuhan hidup dasar, yaitu kebutuhan akan pendidikan dan kebutuhan akan kesehatan. Sehingga apabila pendapatan masyarakat dapat ditingkatkan, maka tingkat kesejahteraan masyarakatpun akan meningkat.

Hasil pengujian atas pengaruh pertumbuhan ekonomi terhadap kesejahteraan masyarakat diperoleh nilai $P$-value yang signifikan $(<0,001)$ memiliki slope positif dengan koefisisen $\beta=0,514$. Artinya, setiap peningkatan pertumbuhan ekonomi, akan berbanding lurus dengan kesejahteraan masyarakat. Semakin tinggi output yang dihasilkan yang tercermin dari nilai PDRB, maka semakin tinggi pulalah tingkat kesejahteraan masyarakat. Hal ini mendukung penelitian yang dilakukan Algifari (2011) yang menganalisis tentang hubungan pendapatan perkapita dengan indeks pembangunan manusia dengan hasil positif signifikan. Demikian juga penelitian Wahyuni yang menyatakan bahwa pertumbuhan eknonomi berpengaruh signifikan dan positif terhadap kesejahteraan masyarakat.

\section{SIMPULAN}

Berdasar analisis hasil pengujian tentang 
pengaruh belanja modal dan investsi swasta terhadap pertumbuhan ekonomi serta dampaknya pada kesejahteraan masyarakat, dapat ditarik simpulan sebagai berikut 1) Belanja modal berpengaruh signifikan dengan hubungan yang positif terhadap pertumbuhan ekonomi dikabupaten/kota di Indonesia. Hal ini berarti semakin besar realisasi belanja modal, maka akan berdampak pada peningkatan pertumbuhan ekonomi. Dengan perolehan hasil pengujian ini, hiphotesis pertama yang menyatakan bahwa belanja modal berpengaruh positif terhadap pertumbuhan ekonomi, diterima; 2) Investasi swasta berpengaruh signifikan dengan hubungan yang positif terhadap pertumbuhan ekonomi. Hal ini menunjukkan bahwa peningkatan investasi swasta akan diikuti peningkatan pertumbuhan ekonomi. Dengan demikian hipotesis kedua, yaitu investasi swasta berpengaruh positif terhadap pertumbuhan ekonomi, diterima; 3) Pertumbuhan ekonomi berpengaruh signifikan dan memiliki hubungan yang positif. Hal ini menunjukkan bahwa peningkatan pertumbuhan ekonomi diikuti dengan peningkatan kesejahteraan masyarakat. Dengan demikian hipotesis ketiga, yaitu pertumbuhan ekonomi berpengaruh positif terhadap kesejahteraan masyarakat, diterima.

Dalam penelitian ini terdapat keterbatasan penelitian yang dapat mempengaruhi hasil penelitian, yaitu 1) Data realisasi investasi yang digunakan tidak mencakup kabupaten/kota secara luas, karena data yang dibutuhkan tidak tersedia; 2) Penelitian ini sulut mengamati kualitas belanja modal, karena angka realisasi belanja modal hanya menggambarkan besaran belanja modal yang terealisasi, tetapi tidak menunjukkan kualitas belanja modal. Berdasar keterbatasan tersebut di atas, maka disarankan 1) Apabila hendak meneliti tentang investasi swasta, agara mendapatkan data realisasi investasi yang mencakup kabupaten/kota secara menyeluruh; 2) Untuk menambahkan indikator-indikator lain seperti tingkat korupsi, total temuan-temuan BPK per kabupaten/kota dan lain-lain, sehingga dapat menggambarkan kualitas belanja modal lebih baik.

\section{DAFTAR PUSTAKA}

Al-Fawwaz, Torki M., 2015, "The Impact of Government Expenditures on Economic Growth in Jordan" (1980-2013), International Business Research. Vol. 9 (1): 2016.

Algifari, 2011, "Hubungan Antara Pendapatan Per Kapita Dan Indeks Pembangunan Manusia", Jurnal Ekonomi \& Bisnis, Vol. 5 (3): 253-264.

Arsyad, Lincolin, 2010, Ekonomi Pembangunan Edisi kelima, Yogyakarta: Unit Penerbit dan Percetakan STIM YKPN.

Badrudin, Rudy, 2012, Ekonomika Otonomi Daerah, STIM YKPN.

Boediono, 1992, Teori Pertumbuhan Ekonomi, Seri Sinopsi Pengantar IImu Ekonomi No. 4, Yogyakarta: BPFE.

D., Sayekti Suindyah, 2010, "Pengaruh Investasi, Tenaga Kerja Dan Pengeluaran Pemerintah Terhadap Pertumbuhan Ekonomi Di Propinsi Jawa Timur”, Ekuitas, Vol. 15 (4): 477 - 500.

Devarajan, Shantayanan, 2013, "The Composition Of Public Expenditure And Economic Growth", Journal of Monetary Economics, Vol. 37 (1996) 313-344.

Dumairy, 1996, Perekonomian Indonesia, Jakarta: Penerbit Erlangga. Erawaty, A.F. Elly dan Badudu, J.S., 1997, Kamus Hukum Ekonomi Indonesia Inggris 1, Jakarta: ELIPS.

Halim, Abdul, 2007, Pengelolaan Keuangan Daerah, Edisi 2, Yogyakarta: UPP Sekolah Tinggi IImu Manajemen YKPN. 
Hasanah, Erni Umi \& Sunyoto, Danang, 2014, Pengantar Ilmu Ekonomi Makro (Teori \& Soal Edisi Terbaru), Yogyakarta: CAPS (Center for Academic Publishing Service).

Haque, Sheikh Touhidul, 2012, Effect Of Public And Private Investment On Economic Growth In Bangladesh: An Econometric Analysis, Research Study Series No -FDRS 05/2013.

Hendarmin, 2012, "Pengaruh Belanja Modal Pemerintah Daerah dan Investasi Swasta terhadap Pertumbuhan Ekonomi, Kesempatan Kerja dan Kesejahteraan Masyarakat di Kabupaten/Kota

Provinsi Kalimantan Barat", JEKSOS, Vol. 8 (3): 144 - 155.

Hukubun, Mefi et. al., 2014, Pengaruh Investasi Pemerintah Dan Investasi Swasta Terhadap Pertumbuhan Ekonomi Dan Dampaknya Terhadap Tenaga Kerja Propinsi Sulawesi Utara Tahun

2002-2012, Fakultas Ekonomi dan Bisnis, Jurusan Ekonomi Pembangunan Universitas

Sam Ratulangi Manado.

Humiang, Maikel. 2016, Analisis Pengaruh Investasi Swasta, Belanja Modal Dan Tenaga Kerja Terhadap Pertumbuhan Ekonomi Di Kota Manado Tahun 2003-2012, Fakultas Ekonomi Dan

Bisnis, Jurusan IImu Ekonomi Pembangunan Universitas Sam Ratulangi, Manado.

http://kbbi.web.id/investasi, diakses pada September 2016.

http://nswi.bkpm.go.id/wps/portal/biumum/!ut/p/c5/04_SB8K8xLLM9MSSzPy8xBz9CP0os3hDAwNPJydDRwN3U1MTA0f_EGOvYDcXYwMDQ_1wkA6zeAMcwNFA388jPzdVvyA7r xwAkmxVPg!!/dl3/d3/L2dBISEvZOFBIS9n-QSEh/, Perkembangan Investasi Di Indonesia, diakses pada 7 November 2016, pukul 10:46 WIB.

http://otda.kemendagri.go.id/NewsOTDA, Daftar Daerah Otonom Di Indonesia Sampai Dengan Desember 2014, diakses pada 6 September 2016, pukul 14:58 WIB.

http://www.antaranews.com/berita/478416/bps-pertumbuhan-57-persen-tergantun pembangunan-infrastruktur, diakses pada september 2016.

Ighodaro, Clement A.U. \& Oriakhi, Dickson E., 2010, Does The Relationship Between Government Expenditure And Economic Growth Follow Wagner's Law In Nigeria?, Annals of the University of Petroşani, Economics, 10(2), 2010, 185-198.

Iheanacho, Eugene, 2016, The Contribution of Government Expenditure on Economic Growth of

Nigeria Disaggregated Approach, International

Journal of Economics \& Management Sciences. Jhingan, M. L., 2012, The Economics of Development and Planning - 40th Revised and Enlarged Edition,

New Delhi: Vrinda Publications (P) LTD. Jogiyanto, H. M., \& Abdillah, Willy, 2014, Konsep Dan Aplikasi PLS (Partial Least Square) Untuk Penelitian Empiris, Yogyakarta: BPFE. Juliandi, Azuar, Ifran \& Manurung, Saprinal, 2014 